\title{
Seven Aspects of the Great Steppe in the Modern Kazakh Prose - the National Conception of Eternal Nation and Art Discourse
}

Ismakova Aigul, ${ }^{\dagger}$ Akysh Nurdaulet, ${ }^{\dagger}$ Akhmetova Ainur, ${ }^{i}$ Kaliyeva Almira, ${ }^{\dagger}$ and Shortanbayev Shokhan $^{\dagger}$

\section{Abstract}

This research aims to identify the role and place of the ideological concepts of the "Eternal Nation" and "The Great Steppe" in Kazakh literature.

For this, it uses methods of stylistic analysis of literary works from the perspective of identifying communication symbols in prose. Additional research methods are the method of historical analysis of the ideological concepts formation and a cross-disciplinary approach to the interpretation of the content of works.

The reasons for the strong influence of these concepts on the culture of modern Kazakhstan are justified. A symbol code is discovered through which writers reflected the state of public life in Kazakhstan.

The research is one of the first attempts to review and analyse the stories of Kazakh literature published in the 21st century. The stories are specially classified in the thematic and content context, the scientific conclusions for the artistic world of the works, language and style features of the works are presented, whereby the authors of the study set a precedent for systematising disparate knowledge of modern Kazakh literature.

Keywords: Kazakh Literature; Nation Idea; Discourse; Eternal Nation; The Great Steppe

\footnotetext{
${ }^{+}$Institute of Literature and Art named after M.O. Auezov, Almaty, Kazakhstan

${ }^{*}$ Corresponding Author, E-mail: a-ismakova@bk.ru

'Al-Farabi Kazakh National University, Almaty, Kazakhstan

(C) 2019 Aigul et al. This is an Open Access article distributed under the terms of the Creative Commons Attribution License (http://creativecommons.org/licenses/by/2.0), which permits unrestricted use, distribution, and reproduction in any medium, provided the original work is properly cited.
} 


\section{Introduction}

Kazakh culture has a rich history, where literature occupies a special place as a carrier of information of the past. These literature reflects not only the facts occurring in society but also serves as a platform for tracking the transformation of the language of the people (Kiynova et al., 2018).

The ideological concepts of the Eternal Nation and the Great Steppe were directly reflected in the vocabulary, figurative and informative content of literary works (Melekhova et al., 2018).

In this research, the concept of Eternal Nation is explained as the source and historical content of the modern national idea of the Kazakh people. The historian Kh. Abzhanov expresses the opinion that the national idea of Eternal Nation, which is important and relevant in the Kazakh literature in the 21st century, appeared as the concept of the Turkic peoples in the ancient Turkic written manuscripts (Abzhanov, 2016).

The national ideological concepts have undergone chronological transformations due to various historical events, and currently they have become an object of study as a broad integrated concept (Sarbassova, 2015).

In this research,we dwell on development of national idea in the history of Kazakhstan.

Narrator's poetry of XV century is considered the primary source of national interest. On the one hand, it was used for maintaining the national concept, security of state, internal solidarity of nation, compliance. On the other hand, for the creation of service ethics of nation's leader and the formation of moral values based on profound knowledge and higher level of consciousness (Abdikuly et al., 2009).

The authoritative figures of the past such as Asan (Grieved Asan, a historical figure who seriously worried about Kazakh nation's future) Kaztugan, Dospambet, Zhiembet, Margaska, Bukhar contributed to the rapid development of a national idea in the territories of Kazakh settlements. They also expanded the semantic meaning and added a new dimension to the functional content of this term (Abdikuly et al., 2009).

The figures of XVIII century like Abylai Khan, Zhantai, Bogenbai, Kabanbai, Syrymbet, and Bayan fought against the disappearance of Kazakh nation from the history. They looked for national idea in multiple red battles. The figures of 19th-20th centuries were Makhambet, Isatai, Kenesary, Nauryzbai, Syrym, Shokhan, Abai, A. Bokeykhan, A. Baytursynov, M. Dulatov, M. Tynyshbaev, T. Ryskulov, S. Saduakasov, M. Auezov, J. Aymauytov, M.Shokai. They encouraged freedom, educational activities, and independence. They also considered the issue of national idea in terms of education, scientific space, art and culture (Abzhanov, 2014).

Comparative Literature Studies (Sailaubaikyzy et al., 2018) reflect the history of the Kazakh people's life, philosophical views, author's artistic decisions and the history of the national idea reflecting the development of the state. Some aspects of the historical and political life of the nation and society are broadly described in literary works rather than in political discourse. Language is one of the national cultural values of Kazakh people (Kiynova et al., 2018). Therefore, the analysis of ideological concepts of Kazakhstan development through literature is highly accurate for determining trends in the transformation of public life.

In light of this backdrop, the key purpose of this research is to identify the role and place of the ideological concepts of the Eternal Nation and The Great Steppe in Kazakh literature. To accomplish this, the study is organised into the following parts:

It begins with a discussion of the methods deployed for this research. It then critically discusses the results.

\section{Methods}

To accomplish the objectives of the research, we have decided to cover only the stories written after the dissolution of USSR, more specifically in 
the first quarter of Kazakhstan's independence and novels written within 2000-2015.

In the course of the study, along with the definition of the national concept of Eternal Nation in the Kazakh novels of the 21st century, the stories of the Kazakh literature were analysed in detail and classified in terms of thematic and content context, analysis of ideas and subject compositions of works was carried out. The following works reflect the national concept of Eternal Nation. These are Ospan batyr by S. Abilkasymuly, Zharylgap batyr by S. Smatayev, Narkesken by A. Ospanov Tar kezen by K. Mukhambetkaliuly, Esengeldi bi, Zharylkap bi, Aytumar by Zh. Akhmadi, Belaskan by K. Segizbay, Kyzyl Zholbarys, Ablaidyn ak tauy" by U. Dospambetov, Uly Kosh by T. Ryskeldiev, 37 zhyldyn balalary by T. Tleukhanov. Along with Karakerey Kabanbay by Z.Tileuzhanov, Kakharly Altai by Zh. Samituly, Tanzharyk by T. Memesseyt, Shyngys Khan zhane onyn zamany by M. Magauin, Ai, dunie-ai by B. Nurzhekeuly, Mustafa Shokai by A. Tarazi (2008). These works are characterised in terms of the thematic and content context of the novels. The author's artistic ideas, national images and characters of novels, which tried to explain the national concept of Eternal Nation to the reader, are analysed. The research presents the concept of Eternal Nation and the reflection of similar ideas in the Kazakh literature such as Oyan, kazak! (Wake up, the Kazakhs!), Korgan bol, Kazak! (Be a protector, Kazakh!), Tutas Turkistan (The whole Turkistan). The scientific works of the researchers are taken as a basis for the study of the concept of Eternal nation in the novels. Besides, in addition to the novels in the Kazakh literature, the article has made a full review of the stories published in separate collections of Kazakh authors or prose collections, which analysed the artistic and aesthetic aspects for the first time.

The list of analysed (stylistically and conceptually, to detect the identifiers of the Kazakh culture) in the article novels (published since independence) are: Mother of Nayman clan, Kokzhal (full-grown wolf) by Kabdesh Zhumagulov, Formula of fat, Fear by Dukenbay
Doszhan, Front of judgment, Mirage of boundless steppes, Happiness and misfortune by Uzakbay Dospanbetov. Along with The songs of Childhood, Kakadu by Tynymbay Nurmagambetov, The kingdom of shadows, Winter of Well-fed vultures by Turysbek Sauketaev, The Last days of Suzge by Sharbanu Beisenova, Hunter, Hero Altynbay, Harsh December, Tint years by Oten Ahmet, Prideful Altai, what do I do with your height by Alibek Askarov. Other novels include Road by Nesipbek Dauitayuly, Apollo butterfly by Kuanysh Zhienbayev, A slander and grief, Cold spell by Zhumabay Shashtaiuly, Cradle and share by Turlybekov Mameseyit, The fog from mountain, Fume of earthen fireplace, Representatives by Nagashybek Kapalbekuly, The white crow by Serik Asylbekuly, Tears of Genghis Khan by Rakhymzhan Otarbayev. As well as The Last youngling of imperial eagle by Seyithan Abilkasymuly, Wealth of Bektore by Talasbek Asemkulov, Sparrow in thrall, Sheep and shepherd by Kuandik Tumenbaev, Kalguty by Kelis Rahymzhanov, First-grader, Earth has a pulse by Zhanabek Shagatay, Honor of two lives by Seitkul Ospanov, The kingdom of angels by Arassanbay Estenov. Along with Ending by Tolymbek Abdiraiym, Flame of love by Dalelbek Batyr, Stomp of horses by Zhumabay Kayranbay. Guiding star, An Old man by Nurlan Kami, I miss you by Didar Amantay, Sounding of Sahara by Eskara Toktasynuly, Goodbye, Love by Bazarhan Zhakybaev, Alien heart by Saule Doszhanova, Red wolf cub by Askar Altai, Man that seeks nothing by Serik Nugyman, Busybody by Kanat Abilkayir and others. Individual author's stylistic features were determined, conclusions about the artistic and aesthetic level of the works were presented in the above-mentioned stories. This research is however based on the scientific and theoretical works of researchers such as Abzhanov (2014; 2016), Kirsch (2017), Dawes (2018), Kristeva (2004), Burns (2019), Smith (2010).

\section{Results and Discussion}

The sociopolitical movement Alash, which transformed into Alash autonomy in 1917, was the de facto first independent Kazakh state. This 
movement indeed kindled the ideas of Kazakh identity and national autonomy. Alash, as a form of organisation of society, united various social groups and ethnic groups living in the territory of present-day Kazakhstan with the ideas of panIslamism, borrowed from the Ottoman Empire (Balpanov et al., 2018). Along with pan-Turkism, which was deeply reflected in the cultural life of Alash society.

Figures of Alash movement ${ }^{1}$ developed genres such as poetry, prose, opinion journalism by directing their plans, orientations to creative activities. Where the message of literary works such as Get up, Kazakh!, Patrial, Address to young people, Unfortunate Zhamal by $\mathrm{M}$. Dulatov, Mosquito, Forty fables by $\mathrm{A}$. Baytursynov, Thought of a learner by $\mathrm{S}$. Toraigyrov is devoted to education, knowledge, gender equality on the way toward awakening the consciousness of Kazakh people.

Furthermore, Alash representatives frequently took up the matters of state, land, religion, attitudes of the newspapers like Kazakh, Kazakhstan, Aykap in addition to favourable conditions in the spiritual, informational fields, which also influenced in the establishment of widening the nationalistic idea (Beissinger, 2002).

According to the historian Kh. Abzhanov, national idea's complex variants like Get up, Kazakh, Kazakh autonomy (originating in ancient Turkic times) had no support after the 1960s. Thus, the concepts of the Great Steppe and the Eternal Nation have retained their popularity and prevalence through literature.

Freedom, liberty, independence, sovereignty are pivotal parts of each national idea (Qazaq romany: otkeni men bugini, 2009). Many writers, who are among those who are responsible for state ideology, have actively participated in the events organised for demonstrating and spreading nationalistic ideas in order to give exemplary character to such dates in the way of

\footnotetext{
${ }^{1}$ The Kazakh national movement led by Russian-educated Kazakh intellectuals in the Russian Empire at the beginning of the 20th century, redefined Kazakh ethnicity into the Kazakh nation (Kesici, 2017).
}

a perfect future, encourage the people to learn from the unfortunate mistakes of the past.

Worries and sorrows of the Kazakh people caused by Karkara, Torgay revolutions ${ }^{2} 100$ years ago were described in the novels like Calamiyous time by M. Auezov, Kartkozha, Akbilek by Zh. Aymauytov.

Writers who lived in the Soviet period could not tell about the historical truth of the revolution based on historical data because of the policy of the government. "Kazakh" idea of Alash representatives affected the artistic sincerity of the novel. For example, in 1917, A. Bukeykhan encouraged the Kazakh people to integrate, protect, team up for attaining the goals.

Character sketch of M. Shokai, who struggled for a national goal not only for the Kazakh people but also for solidarity and compliance of Turkic nations, was described in the novel Mustafa Shokai by A. Tarazi (2008), which fully complies with the principles of pan-Turkism.

M. Shokay reckoned that in the 20th Century globalisation, the impacts of which had already reached the Kazakh people, would integrate all Turkic nations into a single country.In the said context of globalisation, religion has ceased to be an integral factor for the people- ideas unite nations: such as the Great Steppe and the Eternal Nation.

Great Steppe - today, it is more than an ideological concept: it is a broad cultural category, which covers aspects of political governance, cultural identity, including a communication character set (Sarbassova, 2015), and geographical assessment of territories. Great Steppe as a political and ideological management tool, is tightly connected with other concepts of identification of the Kazakh state, representing the exact positioning of the modern Kazakh state for Europe in the geopolitical arena of Asia. At the same time, the Great Steppe remains a systemforming element of the culture of Kazakhstan,

${ }^{2}$ One of the episodes of the civil war in Russia, when Kolchak's offensive began on the Eastern Front in 1919. 
displayed through literature and painting in the form of specific images (horse, kobyz, dombra), thereby creating a symbol of recognition in the world and the image of the homeland for a Kazakh who is forced to be far from home (Melekhova et al, 2018).

The topics that are touched upon in historical Kazakh novels are conventionally grouped into three categories. In the first group, writers look into the issues of the hidden layers before gaining independence, others speculate about the fate of human within the compass of Soviet realism. Representatives of the last group regard the issues of Kazakh society after the collapse of the Soviet Union.

Most of the novels written on historical topics are devoted to the time of Kazakh people's hardships endured for the sake of independence. This group includes Mother of Nayman clan by Kabdesh Zhumadilov, The drop of holy blood by Zukhay Sharbakynuly, The last days of Suzge by Sharbany Beysenova, The Day spent in Tarym by Orazanbay Egeubayuly, Hunter (who hunts with eagle), The person who is like tumbleweed by Omir Karipuly. Along with Tears of Genghis Khan by Rakhymzhan Otarbayev, The Sound of Sahara by Eskara Toktasynuly, Legend of the wise steppe by Adilbek Ibirayimuly.

Among the novels being discussed, there are few ones that are worth to be pointed out by their forms and content. The Monument of Nayman clan by Kabdesh Zhumadilov is an example of this. The storyline that should be developed in two parallels construct the two artistic epochs. In the first epoch, events of today are being developed while in the second one, the reader can imagine the events of 14th and 15th Centuries.

The novel narrates writer Ayzharyk's and sculptor Barak's union of oeuvre devoted to mother Nayman's monument. The writer's exploration of the historical period to explain the character of the sculptor. When depicting ancient period the events, which build the base of the novel, are folk legends and various documentaries. Therefore, Mother Nayman whose name was Kyz Eney and Okiresh Nayman, is the version of historical fibulae offered by the writer. Another novel of Kabdesh Zhumadilov in which Kokzhal (literally mature wolf) narrates about the Hero whose name is Ospan, is built on the events of his own experience. The following arguments explain what is unusual in the novel regarding this personage from another novel:

First, it can be stated that this novel does not repeat others in artistic means. Second, the novel depicts the last days of the main character. Third, , the tragic events have been revealed not only regarding the main character in the novel as well as the events are associated with the tragedy of entire Kazakh people in the past. The main character's image demonstrated the genuine model of a hero when he was in the captivity preparing him to death.

The excess of forced collectivisation, suffered by Kazakh people in Kazakhstan has been depicted in the novel winter of Well-fed vultures by Turysbek Sauketayev and shown in the example of the entire family. The picture in which the main character of the story was not able to find food in the severe nature falling down dying and hugging the snow illustrates the famine.

T. Sauketayev, having shown the death of people in the great famine in detail, tries to reveal contradictory situations deeper from the psychological point of view.

The main character of the novel Hunter by 0 . Karipuly is the father of famous Kazakh writer Saken Seyfullin, Seyfulla. Despite S. Seyfullin's endurance of difficulties, his father's destiny was not at the mercy of fate. The novel clearly describes the nature of Saryarka valley, everyday life, the time when Kazakh culture and traditions were not spoiled by the outer impact. Big and small events that take place are interwoven with the art of hunting with eagle and nature. Thus, the influence of historical and social problems on the personality, moral and humanistic principles, etc., is interpreted not only by the course of the drama (character conflicts) but also realised by the psychology of the characters (Sailaubaikyzy et al., 2018).

Sharbanu Beysenova shows one of the periods of Kazakh history in the novel The last days of 
Suzge. The story narrates one of the aspects of the event how Russian army invaded Siberian Khanate. The main character of the novel is younger wife of Koshim Khan, Suzge. The scene is designed very psychologically skilfully, in which Khan's wife who habituated Siberian forests in order not to be caught by Russian gentiles decides to commit suicide, which emphasised the special place of women as an image in the culture of the Kazakh people (Sharipova et al., 2018).

The novel The sound of Sakhara by Yeskara Toktasynuly is devoted to Kenesary Kasymov, who opposed the Russian colonial oppression in the 19th Century on the southern Kazakh territory, namely in the region of Karatau mountains. In the story, Kenesary is imagined not as fearless, cruel, ruthless commander and warrior, but as a sensitive and wise philosopher.

The scene in the book The song of childhood is the issue of moral and social importance narrating the generation gap occurring at that time. The issue is artistically built around the main character, a teenager, whose name is Bura.

The novel deals with the problem of the generation gap, which is stated as an eternal problem of society. The writer is able to raise this problem through different events and contradictions to make the reader speculate over it. Here, the author skilfully diversifies Kazakh customs and traditions mixing with character typical to Kazakhs.

The main idea in the novel The white crow by Serik Asylbekuly encompasses the position of the person who fights for the truth, in fact, it is impossible to find one's place under the sun according to the assumption of the writer.

One of those novels that aim at showing hardships of the economic transition period in rural area from where habitats moved to urban are is Oten Akhmet's Yer Altynbay, Abandoned seven households by Alibek Askarov that raise the social problems. Writers develop the plot of the story using the disposition of characters and view/mind as a base. On the one hand, the issue of how to save the nature of Kazakh and on the other hand the youth's aspiration to move to cities and the urbanisation process have been observed in the novel.

The novel Taskara by Nurgali Oraz has been developed on the base of the main character, Karim Mendigalyevich's business trip to his native village in the civic service. Despite having such a high position and being able to solve the problem of his compatriot and former friend's daughter, he gave up solving it. The author is able to reveal moral phenomena in people's inner world, their cognition and perception of life as mortals quite well in their novels in the period of independence.

The writing style of The honour of two worlds by Seytkul Ospanov seems strange for the reader. What is to mention here is that the author is applying single/only narration. The powerful novel reveals problems occurred in the period of independence.

The relationship between human and nature has always been one of the main ideas that were the thread of the story. A great number pof novels touch this theme. Eaglet by Turdakyn Zheksenbay, Kermaral, Fracas, Lamentation of the hunter, Mature male wolf by Zeynebil Toyboldy, The last chicken of the truth by Seytkhan Abylkasymuly, Clatter of blood-horse by Zhumabay Kayranbay, Red wolf-cub by Askar Altay stand in this line.

Turdakyn Zheksenbay discusses the topic of the relationship between human and nature. Basic artistic attributes have been implemented that makes the plot attractive and makes distinct characters' behaviour more vivid.

We intentionally focus on the works of abovementioned authors, as they are not able to win the attention of critics and the literary environment because of the biased opinion despite their literary capacity.

Further, some authors, instead of reaching perfection in their writing, are busy with solving trifle issues to meet the literary criteria using empty words, which reduces the value of their works. Often authors cannot build characters of the story by using dialogues and monologues, as 
they are focused on artistic standards (Tsapko et al., 2018).

In most of the above-mentioned works, characters, speeches and thinking manner are similar to that of the author. However, the key drawbacks of these writers are that they have failed to master in converting the real-life events into artistic truth. Another flaw of stories in historical novels is that characters in the events of ancient time speak in the ways that is taking place in the current state. way.

The most urgent issue of today is that the current writing needs describing the real event using artistic devices remain paramount so that the writers are able to render the spirit of Kazakh State. Currently, there are plenty of life materials that are proper to be used in novels. However, few novels are focused on the period of independent Kazakhstan. Their distinguishing feature is that tradition and novelty of novels and stories have adapted to the current state, namely, the processes of globalisation, and as a result, they started merging with each other.

\section{Conclusion}

In the VI-VIII centuries, the national idea of Eternal Nation, founded in the ancient Turkic era, has become a meaningful concept that led national culture to symbolic and ideological identity of Kazakhstan, which is reflected in the image of heroes. The concept of Eternal nation is represented in literary works both historically and politically. Eternal nation in literature is a collective dream image of the Kazakh people, the diverse history and culture of the past, material and spiritual treasures on historical and cultural background.

During the consideration of the artistic aspects of the national concept of Eternal Nation in the genre of the novel, the mechanisms of formation and development of the national idea of an invariant character in the Kazakh literature were determined by the authors of this article. The national idea of Eternal Nation in the novels depicting the historical and social state of the Kazakh people in the XVIII-XIX centuries was propagandised through battles peculiar for the nomadic culture and the conquest of the enemy.
At the beginning of the 20th-21st centuries, it became the basis of the development of the Kazakh society in the sphere of culture, education and science.

Stories reflecting social issues in the Kazakh society were reviewed and analysed. Thematic and content contexts of the stories were classified. The artistic world of individual authors from different perspectives was analysed as well. The axiological concepts are sacred for Kazakh people. Such concepts have been inherited from the history, culture and from a nomadic civilization of the Kazakh people. The concepts include "native land", "horse", "kobyz" (a national musical instrument), "dombra" (a national musical instrument), "nationality"and others. These concepts have been summed up in national literary works.

The study has found that almost all the works on the historical theme are based on independence and nationality and discuss the protection of the native land - the Motherland, where the main idea of epics depicting the history is the integrity and independence of the Kazakh nation and land.

\section{References}

Abdikuly, T. (2009). Parasat maidany. Astana: Foliant, pp. 88.

Abzhanov, Kh. (2016). Mangilik Yel ideasy zhane tauelsiz Kazakhstan zholy. Retrieved from: https://e-history.kz/kz/publications/view/2590

Abzhanov, Kh. (2014). Qazaqstan: ulttyq tarih, idea, metodologia (pp. 328). Almaty: Eltanym.

Balpanov, N., Ismagambetova, Z., Karabayeva, A., Mirzabekova, A., \& Rysbekova, S. (2018). The problem of religious tolerance in Kazakhstan: Past and present. Space and Culture, India, 6(2), 17-33. doi: 10.20896/saci.v6i2.318

Beissinger, M. R. (2002). Nationalist mobilization and the collapse of the Soviet State. Cambridge University Press. Eleukenov, Sh. (2006). Qazaq adebieti tauelsizdik kezenginde. Almaty, Alatau, pp. 352.

Burns, L. (2019). Postcolonialism after world literature (pp. 264). Bloomsbury Academic. 
Dawes, J. (2018). The novel of human rights (pp. 240). Harvard University Press.

Kesici, Ö. (2017). The Alash movement and the question of Kazakh ethnicity. Nationalities

Papers, 45(6), 1135-1149. doi:

10.1080/00905992.2017.1320541

Kirsch, A. (2017). The global novel: Writing the world in the 21st century (pp. 105). Columbia Global Reports.

Kiynova, Z. K. K., Sansyzbayeva, S. K., Akhmetzhanova, A. I., Mussabekova, U. E., \& Muratbayeva, I. S. (2018). Kazakhstan realities in the perception of representatives of American Ethnolinguoculture. Space and Culture, India, 6(3), 71-81. doi:

10.20896/saci.v6i3.370

Kristeva, Yu. (2004). Jest: praktika ili kommunikatsia? Izbrannye trudy: Razrushenie poetiki. M.

Melekhova, K. A., Lichman, Y. Y., Erkin, Z., Raimbergenov, A. I., \& Sagimbayev, A. A. (2018). The role of Central Asian traditions in Mongolian Fine Arts. Space and Culture, India, 6(3), 61-70. doi: 10.20896/saci.v6i3.372
Qazaq romany: otkeni men bugini: Uzhymdyk monografia. (2009) (pp. 664) Almaty: Almaty.

Sailaubaikyzy, B. G., Alibiuly, K. M., \& Kabykenovich, S. A. (2018). The comparative analysis of Kazakh and Polish dramatic works. Space and Culture, India, 6(2), 55-64. doi: 10.20896/saci.v6i2.339

Sarbassova, G. (2015). Language and identity in Kazakh horse culture*/Kazak At Kültüründe Dil ve Bilinç. Bilig, 75, 227.

Sharipova, D. S., Yespenova, A. T., Kobzhanova, S. Z., \& Yergaliyeva, R. A. (2018). Tendencies in women's painting in Kazakhstan in the context of self-identification. Space and Culture, India, 6(2), 113-120. doi: 10.20896/saci.v6i2.361

Smith, A. (2010). Nationalism: Theory, ideology, history (pp. 25-30). Polity.

Tarazi, A. (2008). Mustafa Shokay (pp. 382). Almaty: Zhazushy.

Tsapko, M. I., Valyarovskiy, F. I., Maiboroda, E. T., Khusainova, E. N., \& Varnavskaya, O. O. (2018). Language identity as a unifying identity: Linguistic, ethnopolitical and international legal aspects. Space and Culture, India, 6(2), 121-129. doi: $10.20896 /$ saci.v6i2.360 